\title{
Expression of estrogen receptor (ER) - $\alpha$ and - $\beta$ transcripts in the neonatal and adult rat cerebral cortex, cerebellum, and olfactory bulb
}

\author{
GUO Xing Zhong ${ }^{1, *}$, Jun Da SU, 3, ${ }^{2 * *}$, QING Wen SUN ${ }^{1}$, Bing Hua JIAO1 \\ 1 Department of Biochemistry and Molecular Biology, Second Military Medical University, Shanghai 200433 \\ 2 School of Life Sciences and Medical Engineering, Tongji University, Shanghai 200092, China \\ 3 Shanghai Institute of Physiology, Chinese Academy of Sciences, Shanghai 200031, China
}

\begin{abstract}
In the present study expression of estrogen receptor subtype - $\alpha(\operatorname{ER} \alpha)$ and - $\beta(\operatorname{ER} \beta)$ in the cerebral cortex, cerebellum, and olfactory bulb was investigated and compared between neonatal ( $1 \sim 3$-days-old) and adult $(250 \sim 350 \mathrm{~g})$ rats, using reverse transcription-polymerase chain reaction (RT-PCR). No ERa transcripts were detectable in the adult cerebellum and olfactory bulb, whereas very weak expression of ERa was present in the adult cerebral cortex. No significant difference in ERb transcripts was detectable between the neonatal and adult rats. While transcripts for both ER subtypes were co-expressed in these brain areas of neonatal rats, although ERa expression was significantly weaker than ER $\beta$. Even in the cerebral cortex known to contain both ER subtypes in adult rats, ERa transcripts in neonatal rats were much higher than in adult. These observations provide evidence for the existence of different expression patterns of $\mathrm{ER} \alpha / \mathrm{ER} \beta$ transcripts in these three brain areas between the neonatal and adult rats, suggesting that each ER subtype may play a distinct role in the regulation of differentiation, development, and functions of the brain by estrogen.
\end{abstract}

Key words: Cerebellum, cerebral cortex, estrogen receptor (ER), olfactory bulb, RT-PCR.

\section{INTRODUCTION A}

Estrogen has been known to exert extensive effects via estrogen receptor (ER) on diverse physiological and developmental functions of the brain [1], [2]. It has been observed that the distribution of the classical ER subtype- $\alpha(\mathrm{ER} \alpha)$ and the recently characterized novel ER subtype- $\beta$ (ERb), and their expression patterns (ER $\alpha / \mathrm{ER} \beta$ ) vary greatly among various brain regions[1],[3]. These evidences suggest that each ER subtype may play a different role in estrogen' s effects on the brain.

Previous studies on ER in the brain, however, have been done mainly in adult animals. Little in-

* Corresponding author. Tel: 0086-21-25070881-8016, Fax: 008621-25071770-8010,Email: gxzhb@online.sh.cn

**The first two authors contributed equally to this work. Received Oct-23-2001 Revised Nov-28-2001 Accepted Nov-302001 formation is available concerning ER in neonate, as well as the differences of ER $\alpha / \mathrm{ER} \beta$ expression patterns between the neonatal and adult brain. A previous work revealed that there existed changes of ER $\alpha / \operatorname{ER} \beta$ expression patterns in hippocampus[4] between neonatal $(1 \sim 3$ days $)$ and adult $(250 \sim 350 \mathrm{~g})$ rats. The present study was designed to compare the presence and relative expression level of ER $\alpha$ and ER $\beta$ mRNA in the cerebral cortex, cerebellum, and olfactory bulb of neonatal $(1 \sim 3$ days-old $)$ rats with that of adult $(250 \sim 350 \mathrm{~g})$ rats, by use of highly sensitive reverse transcription-polymerase chain reaction (RT-PCR) techniques. The brain tissues of cerebellum and olfactory bulb were selected to be used in the present study mainly because previous study[3] demonstrated only ER $\beta$ and no ERa expression in these brain areas of adult rats. We wonder whether it is also the same case for ER expres- 
sion in these brain regions of neonatal rats. The cerebral cortex known to contain both ER subtypes in adult rats[3] was also used for comparison.

\section{MATERIALS AND METHODS}

\section{RNA extraction}

Brain tissue collection was done in deeply anesthetized (sodium pentobarbital, $100 \mathrm{mg} / \mathrm{kg}$ ) 12 neonatal ( 1 3-days-old) of either sex, and adult (250-350g) 3 male and 3 female Sprague-Dawley rats. Intact adult males and females were gonadectomized under anesthesia (sodium pentobarbital, $70 \sim 80 \mathrm{mg} / \mathrm{kg}$ ) and allowed to recover for one week before sacrifice. Animals were transcardially perfused with $150 \mathrm{ml}$ (for adult rats) and $30 \mathrm{ml}$ (for neonatal rats) of diethylpyrocarbonate (DEPC)-treated (1\%) $0.9 \% \mathrm{NaCl}$ to eliminate possible ER transcripts that may exist in the blood cells[5]. Entire brain tissues of cerebral cortex, cerebellum, and olfactory bulb pooled from 2 neonatal rats or one adult rat were respectively collected in one tube. Tissue samples $(50 \sim 100 \mathrm{mg}$ mixed tissues for each) were immediately processed for total RNA isolation and purification with Trizol (Gibco BRL). The integrity and quality of total RNA were analyzed by formaldehyde denaturing argarose gel electrophoresis (sharp bands of $18 \mathrm{~s}$ and $28 \mathrm{~s}$ rRNA) and by measurement of the A260/A280 nm ratio $(>1.8)[6]$.

\section{Reverse transcription ( $R T)$}

$2 \mathrm{mg}$ of total RNA (determined by spectrophotometer) together with $1 \mu \mathrm{M}$ oligo-dT (18mer) and $1 \mathrm{ml}$ random hexamer primers $(0.2 \mathrm{mg} / \mathrm{ml})$ was denatured at $65^{\circ} \mathrm{C}$ for $5 \mathrm{~min}$. The RNA was added to a mixture of RT buffer containing $0.5 \mu \mathrm{M}$ of each dNTP, 10U of RNasin, and $4 \mathrm{U}$ of Omniscript reverse transcriptase (Qiagen, Germany) in a final volume of $20 \mu \mathrm{l}$. The reaction was incubated for $1 \mathrm{hr}$ at $37^{\circ} \mathrm{C}$, after which the enzyme was inactivated at $93^{\circ} \mathrm{C}$ for $5 \mathrm{~min}$ and then at $0^{\circ} \mathrm{C}$ for $2 \mathrm{~min}$. The cDNA samples were stored at $-20^{\circ} \mathrm{C}$.

\section{Polymerase chain reaction $(P C R)$}

Design and synthesis of specific sense and antisense primers for ERa, ERb , and internal control (glyceraldehyde-3-phosphate dehydrogenase, GAPDH) were based on the published article[7] and rat DNA sequence information in GeneBank with the aid of Genamics Expression software (Ver.1.1). ERa sense: 5' CCTAACTTGCTCTTGGACAGG-3' ; ERa antisense: 5' CAGCAGCAGGTCATAGAGAGG-3' ; ERb sense: 5' GCCAATCATGTGCACCAGTTCCTT-3' ; ERb antisense: 5' AAAGCCAAGAGAAACGGTGGGCAT-3' . GAPDH sense: 5' TCAACGGCACAGTCAAGGC-3' ; GAPDH antisense: 5' AGGGATGATGTTCTGGGCTG-3' .

The reaction consisted of $0.5 \mu \mathrm{l}$ of $\mathrm{cDNA}, 5 \mu \mathrm{l} 10 \times \mathrm{PCR}$ buffer, $0.1 \mathrm{mM}$ dNTPs, $1 \mathrm{pM}$ of each primer, and $1 \mathrm{U}$ of Taq polymerase (TaKaRa, Japan) in a total volume of $50 \mu \mathrm{l}$. The PCR was run for 35 cycles (each cycle: denaturation, 40 s at $94^{\circ} \mathrm{C}$; annealing, $40 \mathrm{~s}$ at $59^{\circ} \mathrm{C}$; elongation, $40 \mathrm{~s}$ at $72^{\circ} \mathrm{C}$ ) with an initial denaturation of $5 \mathrm{~min}$ at $94^{\circ} \mathrm{C}$ and a final extension at $72^{\circ} \mathrm{C}$ for $10 \mathrm{~min}$. The PCR products were collected and cloned in Pucm-T vector (Sangon, Canada), and all of the DNA sequences of the regions amplified for ERa, ERb and GAPDH were analyzed and verified to fit with the published sequences of their counterparts in GeneBank.

\section{Gel electrophoresis and controls}

PCR products ( $20 \mu \mathrm{l}$ for each) with $2 \mu \mathrm{l}$ of $10 \times$ DNA loading buffer were electrophoresed on $1.7 \%$ argarose gels in $1 \times \mathrm{TAE}$ buffer, stained with ethidium bromide (EB), and photographed by digital camera (GIS-1000, Tanon).

As additional controls for amplification of only cDNA, mock cDNA synthesis (no RT) or PCR lacking template was performed, and no detectable product (equals to background) was generated from any of the negative control reactions.

\section{Values determination and statistical analysis}

For each cDNA sample analyzed, a minimum of 3 independent PCR was performed. Such a performance was repeated six times from different animals. Values were determined from each sample normalized to internal control GAPDH following local area background subtraction. Difference in fluorescence resulting from differences in the number of base pairs of ERa (408bp) and ER $\beta$ (204bp) products (408 vs 204) were corrected by using a factor of 0.5 for ERa. The value (expressed as mean \pm s.e.m) was averaged from data of all individual reactions for each group, and then normalized to the average value (as 1) of ERb (showing the highest level) of neonatal cerebral cortex (NCC).

Statistical analysis was performed using a three-way analysis of variance (ANOVA; $\mathrm{P}<0.05$; factors =age, ER subtype, and brain area), followed by planned pairwise comparisons using Fishers post hoc analysis $(\mathrm{P}<0.05)$, by using the statistical package, SPSS (V10.0) for windows.

\section{RESULTS AND DISCUSSION}

RT-PCR amplification of cDNA, which was reversely transcribed from total RNA isolated from either the neonatal or adult brain tissues, resulted in production of DNA products of the predicted size for $\mathrm{ER} \alpha(408 \mathrm{bp}), \mathrm{ER} \beta$ (204bp), and GAPDH (458bp) (Fig 1). No sex differences of ER mRNA expression were apparent, and therefore, the data from both sexes were pooled and reflect observations of both male and female brain tissues. Comparison of the fluorescent intensity of EB-staining of RT-PCR products indicated that no significant expression differences of ER $\beta$ transcripts existed in the cerebral cortex, cerebellum (Fig 1b), and olfactory bulb (Fig 1d) between the neonatal ( $1 \sim 3$ days) and adult $(250 \sim 350 \mathrm{~g})$ rats $(\mathrm{P}>0.05)$ (Fig 2$)$. However, it was not the case for ERa. No ERa transcripts were seen in the tissues of adult rat cerebellum (Fig 1a) and olfactory bulb (Fig 1d), although 

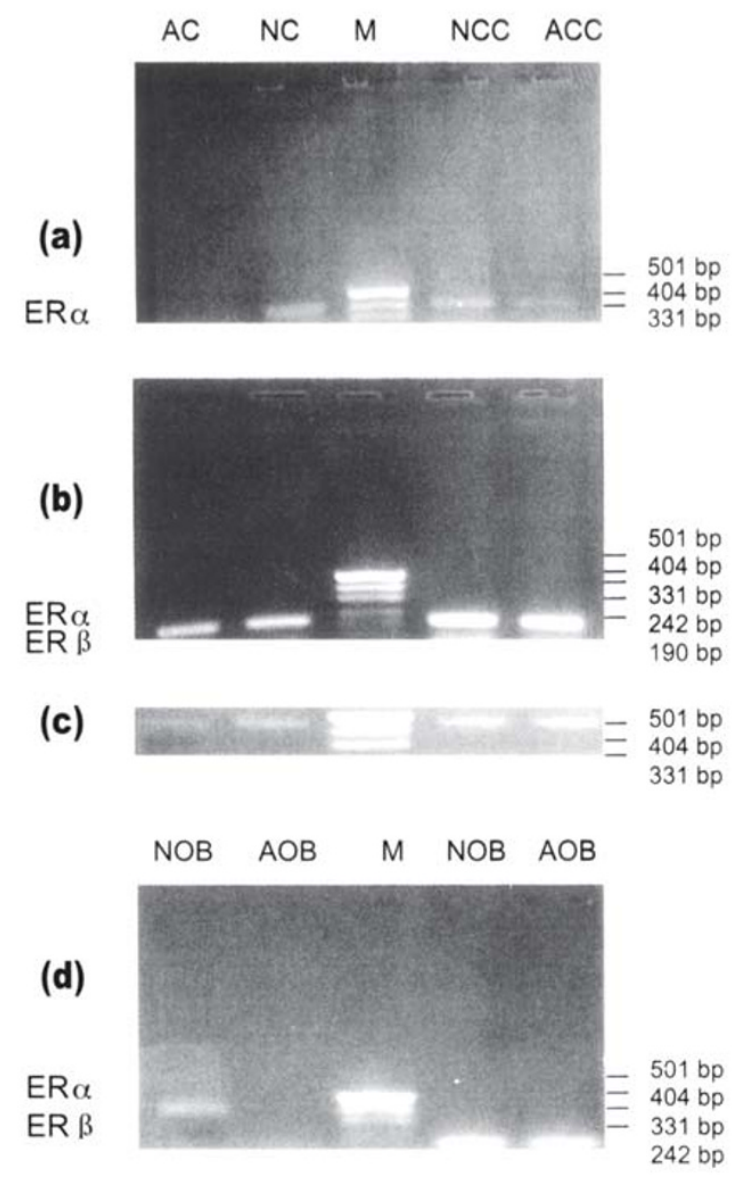

(e)

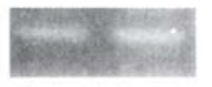

Fig 1. Typical digital photographs of fractionation of RT-PCR products amplified from cDNA of transcripts for either ER $\alpha$ or ER $\beta$ in the cerebral cortex, cerebellum, and olfactory bulb between neonatal and adult rats. Note that no ER $\alpha$ transcripts can be detected in the adult cerebellum (AC) and olfactory bulb (AOB), although very weak expression of ER $\alpha$ transcripts is present in the adult rat cerebral cortex (ACC). Whereas ER $\alpha$ transcripts can be detected clearly, although significantly weaker than $\mathrm{ER} \beta$, in the neonatal rat cerebellum (NC), olfactory bulb (NOB), and cerebral cortex (NCC). Even in the cerebral cortex, ER $\alpha$ transcripts in neonatal rats are much higher than in adult. No significant expression differences of $\mathrm{ER} \beta$ transcripts were detectable in these brain areas between the neonatal and adult rats. (a) ER $\alpha$ in the cerebellum and cerebral cortex; (b) ERa in the cerebellum and cerebral cortex; (c) GAPDH in the cerebellum and cerebral cortex; (d) ER $\alpha$ and ER $\alpha$ in the olfactory bulb. (e) GAPDH in the olfactory bulb. M, marker.

very weak ERa transcripts could be seen in the adult rat cerebral cortex (Fig 1a). Whereas it is worthy of noting that they could be seen clearly in either of these three brain areas of neonatal rats, although significantly weaker than ER $\beta$ transcripts $(\mathrm{P}<0.01)$ (Fig 1a,d; Fig 2). Even in the cerebral cortex known to contain both ER subtypes in adult rats[3], $\mathrm{ER} \alpha$ transcripts in neonatal rats were much higher than in adult $(\mathrm{P}<0.01)$ (Fig 1a; Fig 2$)$.

This RT-PCR study is in agreement with previous reports that $\mathrm{ER} \beta \mathrm{mRNA}[3]$ and its protein immunoreactivity[8] were robustly present, and no $\mathrm{ER} \alpha$ [3],[9] was evidently found, in the cerebellum and olfactory bulb of adult rats, as demonstrated by in situ hybridization and immunohistochemistry techniques. To our surprise, the present highly sensitive RT-PCR study demonstrated that ER $\alpha$ transcripts existed, although in significantly lower degree than ERb, in the neonatal (at least $1 \sim 3$-daysold rats) cerebellum and olfactory bulb. Even in the cerebral cortex known to contain both ER subtypes in adult rats[3],[9], ER $\alpha$ transcripts in neonate were much higher than in adult rats, which is similar to the change of ER expression in the hippocampus as revealed by Western blot analysis[4]. One possible explanation for this discrepancy is that there may exist obvious changes of ER $\alpha$ expression across the structural and functional development of these brain areas from neonatal to adult. In contrast to $\mathrm{ER} \alpha$, no significant expression change of ER $\beta$ transcripts was seen in these three brain areas between neonatal and adult rats. Previous observations reported that $\mathrm{ERb}$ also exhibited developmental changes even during the postnatal period in the cerebellum[10], [11] and olfactory bulb[12]. Our experiments only observed the differences of ER expression between neonatal ( $1 \sim 3$-days-old) and adult (250 350g) rats. Hence, our conclusion could not exclude the possibility that ERb also runs a changing profile across the developmental course from neonatal to adult.

Although the detected variations in ER mRNA expression were not confirmed at the protein level, the present results confidently suggest that the relative expression of $\mathrm{ER} \alpha$ and $\mathrm{ER} \beta$ could not only exist among various brain regions, but also be not static developmentally with age. Nothing has yet been known of the regulation of the relative expression of $\mathrm{ER} \alpha$ and $\mathrm{ER} \beta$ in the brain. It seems that both ER subtypes are co-expressed in these brain areas at least in the early postnatal stage, and then ER $\alpha$ expression is lowered to the degree even below the 
detection levels of some methods available at present such as immunocytochemistry, in situ hybridization, and RT-PCR as seen in the present observations, as animals grow into adult. Although comparison of just two ages gives only a small snapshot of developmental changes of ER expression, the results strongly suggest that each ER subtype may play a distinct role in these brain regions. Most likely mechanism is that either ER subtype is expressed in different brain regions with distinct ontogenic pro-

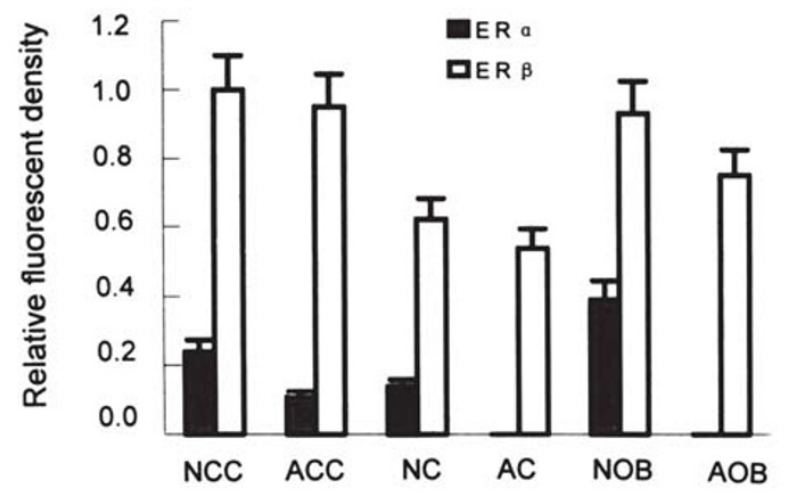

Fig 2. Analysis of the relative fluorescent intensity of ER $\alpha$ and ER $\beta$ products. For determination of values and results of statistical analysis please see text. Abbreviations are the same as used in Fig 1.

file and is governed by intrinsic developmental programs[13].

Our data both in neonatal and adult rats are consistent with the notion that $\operatorname{ER} \beta$ is the predominant ER species expressed[3],[9], [11] and suggest that $\mathrm{ER} \beta$ isoform other than $\mathrm{ER} \alpha$ plays a major role in the regulation of these three brain areas by estrogen. The clear manifestation of ER $\alpha$ mRNA in the neonatal corresponding brain areas, however, merits attention to its role in the regulation of early postnatal differentiation and development of these brain areas by estrogen, since ER $\alpha$ is supposed closely related to cellular differentiation and sexual differentiation of developing brain[14],[15].

\section{ACKNOWLEDGMENTS}

This work was supported by the National Natural Science Foundation of China (No. 39700053).

\section{REFERENCES}

[1] Donahue JE, Stopa EG, Chorsky RL et al. Cells containing immunoreactive estrogen receptor-a in the human basal forebrain. Brain Res 2000; 856:142-51.

[2] Shughrue PJ, Merchenthaler I. Estrogen is more than just a "sex hormone" : novel sites for estrogen action in the hippocampus and cerebral cortex. Front-Neuroendocrinol 2000; 21:95-101.

[3] Shughrue PJ, Lane MV, and Merchenthaler I. Comparative distribution of estrogen receptor - $\alpha$ and - $\beta$ mRNA in the rat central nervous system. J Comp Neurol 1997; 388: 507-25.

[4] Su JD, Qiu J, Zhong YP, Li XY, Wang JW, and Chen YZ. Expression of estrogen receptor (ER)- $\alpha$ and $\beta$ immunoreactivity in hippocampal cell cultures with special attention to GABAergic neurons. J Neurosci Res 2001; 65:396402.

[5] Tornwall J, Carey AB, Fox RI, Fox HS. Estrogen in autoimmunity: expression of estrogen receptors in thymic and autoimmune T cells. J Gend Specif Med 1999; 2: 33-40.

[6] Ma YH, Hu JH, Zhou XG et al. g-Aminobutyric acid transporter (GAT1) overexpression in mouse affects the testicular morphology. Cell Res 2000; 10:59-69.

[7] Sugino N, Zilberstein M, Srivastava RK et al. Establishment and characterization of a simian virus 40-transformed temperature-sensitive rat luteal cell line. Endocrinolgy 1998; 139:1936-42.

[8] Shughrue PJ, Merchenthaler I. Distribution of estrogen receptor-b immunoreactivity in the rat central nervous system. J Comp Neurol 2001; 436:64-81.

[9] Laflamme N, Nappi RE, Drolet G, Labrie C, Revest S. Expression and neuropeptidergic characterization of estrogen receptors (ERa and ERb) throughout the rat brain: anatomical evidence of distinct roles of each subtype. $\mathrm{J}$ Neurobiol 1998; 36:357-78.

[10] Belcher SM. Regulated expression of estrogen receptor a and $\mathrm{b}$ mRNA in granule cells during development of the rat cerebellum. Brain Res Dev Brain Res 1999; 115:5769.

[11] Jakab RL, Wong JK, and Belcher SM. Estrogen receptor $\mathrm{b}$ imunoreactivity in differentiating cells of the developing rat cerebellum. J Comp Neurol 2001; 430:396-409.

[13] Wong CC, Poon WH, Tsim TY, Wong EYK, Leung MS. Gene expressions during the development and sexual differentiation of the olfactory bulb in rats. Brain Res Dev Brain Res 2000; 119:187-94.

[14] O'Keefe JA, Pedersen EB, Castro AJ, Handa RJ. The ontogeny of estrogen receptors in heterochronic hippocampal and neocortical transplants demonstrates an intrinsic developmental program. Brain Res Dev Brain Res 1993; 75:105-12.

[15] Wagner CK, Pfau JL, De Vries GJ, Merchenthaler IJ. Sex differences in progesterone receptor immunoreactivity in neonatal mouse brain depend on estrogen receptor a expression. J Neurobiol 2001; 47:176-82.

[16] Yokosuka M, Okamura H, Hayashi S. Postnatal development and sex difference in neurons containing estrogen receptor-a immunoreactivity in the preoptic brain, the diencephalon, and the amygdala in the rat. J Comp Neurol 1997; 389:81-93. 